\title{
ELECTORAL EXPRESSION WITH INSTITUTIONAL BOUNDS: FRAMING JUDICIAL TREATMENT OF ELECTIONS IN NEW ZEALAND
}

\section{David Bullock*}

This article explores the way in which the courts have treated cases involving electoral broadcasting in New Zealand. Cases involving electoral broadcasting have been decided on a range of approaches. This article uses an "institutional" conception of elections to determine whether certain bounds can be drawn to define a category of election expression, comprising certain rules and norms, which the courts can use when dealing with expression around elections. New Zealand's case law to date is broadly consistent with an institutional model of electoral expression within which a higher level of judicial scrutiny of broadcasters is exhibited. This paper proposes that an express recognition of this institutional conception would provide some clarity and unity to decisions involving the sensitive issue of electoral broadcasting.

\section{INTRODUCTION}

New Zealand authorities on electoral law appear infrequently. This is possibly due to the "subsidiary role" played by the judiciary in New Zealand compared to jurisdictions where "higher law" gives courts greater scope to review issues of campaign funding and electoral legislation. ${ }^{1}$ Despite this, the courts have historically played a role in shaping the nature of elections in New Zealand. ${ }^{2}$ This role has continued in a number of decisions in recent years. In particular, the

* Submitted as part of the LLB(Hons) programme at Victoria University of Wellington. Recipient of the 2010 Robert Orr McGechan Prize. I would like to thank Dean Knight and Claudia Geiringer for their comments.

1 Andrew Geddis "Regulation of Campaign Funding in New Zealand: Practices, Problems and Prospects for Change" in KD Ewing and S Issacharoff (eds) Party Funding and Campaign Financing in International Perspective (Hart Publishing, Oxford, 2006) 13 at 14.

2 Jonathan Boston and others "Courting Change: The Role of the Judiciary in Altering an Electoral System" (1997) 4 PLR 229; S Corben "Financing Political Party Broadcasting" (1997) 8 Auckland U L Rev 265. 
judiciary has played an important role in the application and development of electoral broadcasting law and electoral expression in New Zealand.

The most recent addition to this small yet not insignificant pool of electoral decisions is the decision of the Court of Appeal in Alliance Party v Electoral Commission (Alliance). ${ }^{3}$ The Alliance Party challenged the allocation of funding and free air time that it had received from the Electoral Commission preceding the 2008 General Election. In reaching its decision, the Court stated: "statutory language should be read, if reasonably possible, in a way which facilitates the important democratic feature of dissemination of election messages." 4 The Court of Appeal's statement is of interest for both what it says and what it leaves unsaid in an area fraught with conceptual difficulties and competing philosophies. ${ }^{5}$

The meaning of "election messages" is not self-evident, particularly whether a distinction exists between "electoral" expression and general political expression. There is a risk that any regulation of electoral expression through the control of broadcast access may infringe on rights of legitimate political expression. To avoid this, a conception of electoral expression must be defined to sufficiently separate it from other political expression. New Zealand's electoral broadcasting legislation and case law exhibit the demarcation of an "electoral institution", distinct from other general political activity, enabling the delineation of a distinct conception of electoral expression in New Zealand.

I draw upon the work of scholars such as C Edwin Baker, Richard Briffault and Burt Neuborne who have contributed to the development of an "institutionally bounded" conception of elections and electoral expression, and in particular electoral broadcasting. An "institution" in this context refers to the rules, norms and practices that define a conception of elections as separate from other political spheres. The electoral "institution" comprises particular rules and bounds that operate in the context of an election, enabling a line (albeit a blurry one) to be drawn between electoral expression and political expression. This boundary is drawn on both the temporal and descriptive levels. I argue that New Zealand's electoral case law indicates increasing recognition that, at least implicitly, within the context of such institutional bounds, actors may be exposed to greater review by the courts and held to higher standards of conduct. This paper will focus on electoral broadcasting as a case study, but similar institutional bounds could be drawn for election advertising generally. Framing elections as subject to institution bounds can aid judges and counsel in framing issues in cases involving the balancing of rights during elections.

3 Alliance Party v Electoral Commission [2010] NZAR 222 [Alliance Party (CA)].

4 Ibid, at [35].

5 Andrew Geddis "Three conceptions of the electoral moment" (2003) 28 AJLP 53 at 75. Geddis highlights the difficulties of many competing positions, noting at 75 that "some electoral practices and consequences that are unacceptable under one normative vision of the voting process will be considered not only tolerable, but even necessary, under another". 


\section{ELECTORAL BROADCASTING AND THE 2008 GENERAL ELECTION: ALLIANCE PARTY V ELECTORAL COMMISSION}

The decision of the Court of Appeal in Alliance provides answers to a number of technical questions as to the application of the Broadcasting Act 1989 to political parties during an election campaign. In particular, it clarifies the requisite mechanism for the Electoral Commission's allocation of airtime and funding to parties for broadcast advertising. More than that, the decision of the Court of Appeal raises further questions about the wider treatment of elections in New Zealand. Specifically, can electoral expression be defined as a distinct category of expression, separate from that which occurs during wider political discourse?

\section{A Facts and Procedural History}

Political parties' access to broadcast media for the purposes of electoral advertising is tightly regulated through Part 6 of the Broadcasting Act 1989 (the Act). ${ }^{6}$ The Act regulates broadcast access in two key ways. First, New Zealand's publically owned broadcasters, Television New Zealand (TVNZ) and Radio New Zealand (RNZ), are required to provide free time for the broadcasting of opening and closing addresses by political parties in the lead up to an election. ${ }^{7}$ Broadcasters are required to have regard to the six factors mentioned in $\mathrm{s} 75$ when providing time for these broadcasts. ${ }^{8}$ Secondly, the Act requires that public money be made available to the Electoral Commission (the Commission) to be allocated to parties to pay for the costs of election broadcast advertising. ${ }^{9}$ The allocation of public funds to parties is complemented by a prohibition on the spending of any other money to purchase election programmes. ${ }^{10}$

6 Andrew Geddis Electoral Law in New Zealand: Practice and Policy (LexisNexis New Zealand, Wellington, 2007) at 159-172.

7 Broadcasting Act 1989, s 71(1).

8 Ibid, s 71A(4)

9 Ibid, s 74. The amount provided for the 2008 General Election was $\$ 2,855,000$ excluding GST, or $\$ 3,211,875$ including GST.

10 Ibid, s 70(2)(b). There are other limited exceptions: s 70(2)(c) allows paid advertising in relation solely to a named constituency candidate. This may not be advertising for the candidate's party and must not exceed the candidate's campaign spending limit. Given the tight spending restrictions placed on individual candidates, this exception has little effect. Advertisements by the Electoral Commission and other named election officials are exempted as are non-partisan advertisements broadcast, as a community service, by the broadcaster (s 70(2)(c) and (d) respectively). Spending restrictions do not limit the funds a party may spend on the production of its electoral programmes and do not prevent the broadcast of election programmes in the form of news, comment or current affairs (ss 70(2A) and 70(3) respectively). A number of recent Electoral Commission decisions have clarified the news, comment or current affairs exception. A live broadcast of the Prime Minister's election date announcement was a news programme (Electoral Commission decision 2008-41 (3 November 2008)) but a talkback radio show hosted by a number of MPs who made statements encouraging listeners to vote for their particular parties bore "none of the general 
The Commission is charged with allocating this pool of time and money between eligible political parties in accordance with criteria specified in the Act. ${ }^{11}$ These allocations are made by the Commission having regard to six factors considered exhaustive by the Commission. ${ }^{12}$ They are: the number of votes the party and its candidates received at the previous election or any intermediate by-election; the party's current number of members of Parliament; any relationships that exist between parties; indications of public support from opinion polls and party membership; and the need to provide a fair opportunity for each party to convey its policies to the public by the broadcasting of election programmes on television.

The Commission's allocation decision preceding the 2008 general election split funding into four bands: $:^{13}$

(1) The major parliamentary political parties, Labour and National, each received $\$ 1,000,000$, 12 minutes for an opening address and six minutes for a closing address.

(2) Parties holding four or more parliamentary seats - the Green Party, Māori Party and New Zealand First - were each allocated $\$ 240,000$, eight minutes opening and three minutes closing.

(3) Other parliamentary parties - the ACT Party, Progressive and United Future - were each allocated $\$ 100,000$, four minutes opening and three minutes closing.

(4) Non-parliamentary parties were each allocated $\$ 10,000$, a production package worth over $\$ 7,000$ and one minute for an opening address. These parties were not allocated time for a closing address.

The Alliance Party, which had won only 0.07 per cent of the vote in the previous 2005 general election, and was not represented in Parliament, challenged the Commission's allocation by way of judicial review. Despite the challenge faltering in the High Court at first instance, the Court of Appeal ultimately upheld one of the two prongs of the Alliance's attack.

\section{B All About Time and Money: The Alliance Litigation}

The Alliance's first challenge was to the interpretation the Commission had applied to the Act both during the 2008 allocation process and during a number of previous elections. It was argued the

indicators of a current affairs programme", so was in breach of the Act (Electoral Commission decision 2008-34 (18 September 2008)).

11 Ibid, s 75(1).

12 Ibid, s 75(2). Regarding the exhaustiveness of the criteria see Electoral Commission Te Kaitiaki Take Kowhiri, on Allocation of Time and Money to Political Parties for Broadcasting of Election Programmes: 2005 General Election (Electoral Commission, Wellington, 2005).

13 See Alliance Party (CA), above n 3, at [24]. 
Commission had erred in law by not allocating time for an opening and a closing address to the nonparliamentary parties, contrary to the wording of s 73(1) of the Act, which reads:

In respect of each election period, the Electoral Commission must allocate to political parties, in such proportions as the Electoral Commission considers appropriate, the time that TVNZ and RNZ have made available for opening addresses and closing addresses in accordance with section $71 \mathrm{~A}$.

The Commission had interpreted the discretion given by the words "as the Electoral Commission considers appropriate" as being the operative words of the section. ${ }^{14}$ Given this discretion, it argued that the Commission was free to allocate time to parties as it saw fit, and importantly, that this phrase contemplated the Commission choosing to make a nil allocation of time to a particular party or "band" of parties. This submission found mixed favour in the decision of MacKenzie J in the High Court whose analysis focused on the New Zealand Bill of Rights Act 1990 (Bill of Rights Act). MacKenzie J did not accept that the Act, read in light of the Bill of Rights Act, contemplated that no allocation of time be made to a party, as this would offend freedom of expression. ${ }^{15}$ Despite finding that some allocation of time needed to be made, his Honour was willing to accept that the Act only contemplated that time needed to be allocated in one of four components (being a matrix of $\mathrm{TVNZ} / \mathrm{RNZ}$ and opening/closing). ${ }^{16}$ Consequently, the Commission's decision to only allocate time for an opening address did not contravene the Broadcasting Act.

On appeal by the Alliance, the Court of Appeal overturned the decision of the High Court. The Court of Appeal held that the proper reading of the section required the Commission to provide time for both an opening and a closing address. The Court found that this conclusion could be maintained on the face of the plain words of s 73(1) without need to resort to the Bill of Rights Act or instruments of statutory interpretation. However, Hammond J, writing for the Court, continued: ${ }^{17}$

If there is any doubt about the meaning of the words, that meaning should be preferred which accords with the critical context of this allocation: that of a general election. Statutory language should be read, if reasonably possible, in a way which facilitates the important democratic feature of dissemination of election messages.

This statement is a strong one; it requires that ambiguities be construed in a way that is most consistent with the right in question. It is certainly not consistent with the test currently favoured for the application of the Bill of Rights Act set out in $R v$ Hansen, as that test first involves an inquiry

14 Alliance Party v Electoral Commission HC Wellington CIV-2008-409-1253, 18 September 2008 at [12] [Alliance Party (HC)]

15 Ibid, at [11]

16 Ibid, at [14].

17 Alliance Party (CA), above n 3, at [35]. 
into justified limitations under s $5 .{ }^{18}$ Hammond J's statement bears a closer resemblance to Elias CJ's alternative test in $R v$ Hansen which primarily focused on s 6 and rights consistency. ${ }^{19}$ However, the statement looks most similar to the common law "principle of legality", a tool of statutory interpretation available to the courts to interpret legislation consistently with fundamental rights. ${ }^{20}$ Lord Hoffmann's classic formulation of the principle is that Parliament cannot override "fundamental rights" with general or ambiguous words and consequently the courts will presume that Parliament intended general words to be read consistently with fundamental rights. ${ }^{21}$ The application of Lord Hoffmann's principle in New Zealand has found support in a number of decisions of the New Zealand Supreme Court. ${ }^{22}$

The Alliance's second head of attack in both the High Court and the Court of Appeal was that the Commission had failed to have regard to a mandatory consideration and had taken in account an irrelevant factor in the decision to allocate $\$ 10,000$ to non-parliamentary parties. The basis of the Alliance's challenge drew upon the explanation accompanying the Commission's allocation decision, which stated "the minimum amount allocated reflects the cost of a basic radio advertising campaign for a month". ${ }^{23}$ The Alliance argued that this was an irrelevant consideration (the cost of a one month radio advertising campaign was not included on the exhaustive list provided in $\mathrm{s} 75(2)$ ). Further, it argued that it evidenced a failure by the Commission to have regard to $s$ 75(2)(f), a mandatory relevant consideration, which directs the Commission to consider the need to provide a fair opportunity for each political party to convey its policies to the public by the broadcasting of election programmes on television.

The High Court refused the Alliance's application on the ground that it was feasible that parties could spend the money allocated on television advertising if they wished. ${ }^{24}$ The Court of Appeal also refused to uphold the Alliance's application. The statement by the Commission did not

$18 \quad R v$ Hansen [2007] NZSC 7, [2007] 3 NZLR 1 per Tipping J.

19 Ibid, at [15], per Elias CJ.

20 For an analysis of the role of the "principle of legality" in New Zealand, see Claudia Geiringer "The Principle of Legality and the Bill of Rights Act: A Critical Examination of $R v$ Hansen" (2008) 6 NZJPIL 59. For an English perspective, see SH Bailey Cases, Materials and Commentary on Administrative Law (Sweet \& Maxwell Ltd, London, 2005) 251-270; Douglas E Edlin "From Ambiguity to Legality: The Future of English Judicial Review" (2004) 52 Am J Comp L 383.

$21 \quad R v$ Secretary of State for the Home Department, ex parte Simms [2000] 2 AC 115 (HL) at 131.

22 Cropp v A Judicial Committee [2008] NZSC 46, 3 NZLR 774 at [27]; $R$ v Hansen, above n 18, at [13]. In Hansen, at [13] Elias CJ went further to suggest that legislative ambiguities may be unnecessary for the courts to prefer a rights consistent interpretation.

23 This document was reproduced in full by the Court of Appeal, above n 3, at [26].

24 Alliance Party (HC), above n 14, at [23]. 
"preclude the possibility that it had turned its mind to the cost of a television campaign". ${ }^{25}$ The Court considered the matter a moot point as the allocation had already taken place. ${ }^{26}$ Further, the Court expressed reluctance at intruding upon matters relating to the election of members of Parliament unless "absolutely necessary to determine lawfulness". ${ }^{27}$ However, this did not stop the Court warning the Commission that, in as much as the Commission had based its decision on the cost of a basic radio advertising campaign - which was the only consideration mentioned in its explanation - this would be in error. ${ }^{28}$

\section{Implications of the Decision}

The unanimous decision of the Court of Appeal to partially overturn the decision of the High Court was a muted victory for the Alliance, the 2008 election already having taken place. However, the Court's obiter dicta can be seen as a stern warning for those involved in electoral broadcasting. The Court expressed sympathy for the Commission, noting the difficulty it faced having to allocate the 30 minutes of time provided for closing addresses between 18 qualifying parties. ${ }^{29}$ This led the Court to suggest that there was a strong argument that TVNZ's allocation had been in breach of the Act by failing to provide sufficient time given the number of qualifying parties. ${ }^{30}$ The Court suggested that this might have been a breach of $\mathrm{s} 71 \mathrm{~A} .{ }^{31}$ This section requires the broadcasters to consider the s 75 criteria when making their proposals on the provision of free airtime. ${ }^{32}$ By not providing sufficient time for both an opening and a closing address TVNZ may have failed to consider s 75(2)(f) which required a fair opportunity for each party to convey its policies to the public by the broadcasting of election programmes on television.

Arguably, this breach could have also been in regard of s 71. Broadcasters are required, under Section 71A, to provide statements and proposals of available time to the Commission, whereas s 71(1) requires that such an allocation actually be made. In light of this decision the words of $\mathrm{s} 71(1)$ could arguably be read as:

25 Alliance Party (CA), above n 3, at [43].

26 Furthermore, the 2008 election had already taken place, the Alliance Party winning 0.08 per cent of the vote.

27 Alliance Party (CA), above n 3, at [43].

28 Ibid.

29 Ibid, at [34].

30 Ibid.

31 Ibid.

32 Broadcasting Act 1989, s 71A(4). 
TVNZ and RNZ must each provide [sufficient] time, free of charge, for the broadcasting, in an election period, of the opening addresses and closing addresses of political parties.

A number of issues are raised by the Court of Appeal's decision, particularly for those organisations, like the Electoral Commission and public broadcasters, involved in apportioning broadcast access during elections. The Electoral Commission in particular will have to make alterations to the allocations methodology that has been used in previous elections. ${ }^{33}$ TVNZ may also have to work more closely with the Commission before it makes a provision of time available, to ensure that it provides sufficient free time that an opening and closing address can be allocated to all eligible parties. If this does not occur, there may be future challenges by parties not only against the Commission but also, in light of the Court's decision, against TVNZ. Finally, the Commission will need to ensure that its reasons for allocation are both fully stated and consistent with the criteria established in the Act.

\section{ELECTIONS, EXPRESSION AND "INSTITUTIONAL BOUNDS"}

Looking beyond the decision in Alliance, what is to be made of the Court of Appeal's statement that "statutory language should be read, if reasonably possible, in a way which facilitates the important democratic feature of dissemination of election messages"? $?^{34}$ It is important to distil the meaning of "election message". In particular, is there something about elections and electoral expression that sets it apart from the wider political sphere?

A category of electoral expression can be delineated using "institutional bounds" which frame the extent and nature of expression in the context of an election. To define these bounds I examine a model of elections and electoral expression developed by three leading First Amendment scholars: C Edwin Baker, Richard Briffault and Burt Neuborne. ${ }^{35}$ This model holds that a number of features of elections, and associated expression, are governed by particular rules and norms. I then examine a line of New Zealand cases, most relating to the judicial review of broadcasters during elections, to show that this model has been implicitly recognised in the New Zealand courts. The judiciary, as

33 Allocations of a single minute for an opening address and no closing address had also been made under fundamentally the same statutory scheme preceding the 2005 election.

34 Alliance Party (CA), above n 3, at [35].

35 C Edwin Baker "Campaign Expenditures and Free Speech" (1998) 33 Harv CR-CL L Rev 1; Richard Briffault "Issue Advocacy: Redrawing the Election/Politics Line" (1999) 77 Tex L Rev 1751; Burt Neuborne "The Supreme Court and Free Speech: Love and a Question" (1998) 42 St Louis U L J 791. For a critical analysis of these authors' models, see Lillian R BeVier "The Issue of Issue Advocacy: An Economic, Political, and Constitutional Analysis" (1999) 85 Va L Rev 1761. BeVier argues that the institutionally bounded conception of elections has developed in response to the United States Supreme Court decision in Buckley v Valero 424 US 1 (1976) but despite this, the model and dichotomy posed by the institutional model (namely that electoral spending/speech can be distinguished from political spending/speech) is not supported by the decision in Buckley $v$ Valero. 
ultimate overseers of the electoral process, have an important role to play in defining the extent and bounds of electoral expression. ${ }^{36} \mathrm{I}$ argue that framing the balancing of rights at election time in terms of institutional bounds can aid both counsel and the courts.

\section{A Electoral Expression with "Institutional Bounds"}

The use and meaning of the term "institution" in this context requires elaboration. Often "institution" is treated as synonymous with "organisation". However, in this article I use "institution" in its wider, technical meaning that is more frequently attributed to it in economic, political and sociological theory. North's seminal definition of institutions defines them as "the rules of the game in a society or, more formally, the human devised constraints that shape human interaction". ${ }^{37}$ An institution comprises "the conventions, norms and formally sanctioned rules of a society". ${ }^{38}$ Institutions govern behaviour, structure society and enable social cooperation, coordination and interaction. ${ }^{39}$ A conception of an election as an institution comprises particular rules, norms and principles governing elections and constrains the expression that occurs within.

The Bill of Rights Act guarantees a wide right of freedom of expression, providing that "[e]veryone has the right to freedom of expression, including the freedom to seek, receive, and impart information and opinions of any kind in any form". ${ }^{40}$ The application of the right of freedom of expression recognised in the Bill of Rights Act is constrained, however, by such reasonable limits "as can be demonstrably justified in a free and democratic society". ${ }^{41}$ Jurists have posited a number of different forms of expression encompassed in "freedom of expression", including political, cultural, commercial and artistic expression. ${ }^{42}$ Political expression is often singled out from these categories as the type of expression most deserving of protection, and the least appropriate for

36 Boston and others, above $\mathrm{n} 2$, at 231.

37 Douglass C North Institutions, Institutional Change and Economic Performance (Cambridge University Press, Cambridge, 1990) at 3.

38 Arild Vatn Institutions and the Environment (Edward Elgar Publishing Inc, Northampton, 2005) at 60.

39 Maria Minniti and Moran Lévesque "Recent Developments in the Economics of Entrepreneurship" (2008) 23 Journal of Business Venturing 603 at 608. Indeed, given the potential for definitional confusion "institution" may not be the most appropriate term to describe the rules and norms governing elections. However, due to the prevalence of the term in the relevant literature I have continued to employ it here.

40 New Zealand Bill of Rights Act 1990, s 14.

41 Ibid, s 5. For commentary on the application of the Bill of Rights Act, see generally A Butler and P Butler The New Zealand Bill of Rights Act: a commentary (LexisNexis, Wellington, 2005); P Rishworth and others The New Zealand Bill of Rights (Oxford University Press, Auckland, 2003).

42 Campbell v MGN Ltd [2004] UKHL 22, [2004] AC 457 at [148]; Müller and others v Switzerland (1991) 13 EHRR 212 (ECHR) 
regulation. ${ }^{43}$ The sanctity with which political expression is regarded is, of course, not without cause. The ability to criticise elected officials, protest against their decisions and to engage in political discourse are fundamental to a healthy democracy. ${ }^{44}$ This is all the more important where a constitution is founded upon a sovereign Parliament; free political expression becomes a key mechanism for political accountability.

Expression seen in the "pre-election period" bears many similarities to healthy political expression. ${ }^{45}$ It involves criticism of government policy, the accountability of incumbent representatives, and the presentation of alternative ideas, philosophies and policies. Notwithstanding this, there is something different about electoral expression. In the lead up to elections, states across the Western world regulate expression, quietening the voices of some and enhancing the amplification of others in a way that rarely occurs in other political contexts. ${ }^{46}$ However, there is a risk that without a sufficiently defined concept of "electoral expression" or "election messages" policies designed to regulate electoral expression may encroach on other expression, particularly wider political discourse. ${ }^{47}$

The exceptionality of elections and electoral expression touches on the very legitimacy of democracy and democratic institutions. ${ }^{48}$ The rules, practices and norms that make up the institution of public decision making, combined with a wider, non-election-centred view of politics, ${ }^{49}$ enable an election to be viewed as a "distinct institutional moment". ${ }^{50}$ An election, Baker argues, should be regarded as a legally structured governing institution. ${ }^{51}$ It is from an institutional conception of elections that an "institutionally bounded" definition of electoral expression can be established. In other words, expression can be constrained within the bounds of rules and norms comprising the

43 Campbell v MGN Ltd, ibid, at [148]. Baroness Hale stated at [148] that "there are undoubtedly different types of speech, just as there are different types of private information, some of which are more deserving of protection in a democratic society than others. Top of the list is political speech."

44 Bowman v United Kingdom (1998) 26 EHRR 1 (ECHR) at 16-18.

45 Briffault, above n 35, at 1753.

KD Ewing and S Issacharoff "Introduction" in KD Ewing and S Issacharoff (eds) Party Funding and Campaign Financing in International Perspective (Hart Publishing, Oxford, 2006) 1 at 6.

47 Neuborne, above n 35, at 810. Neuborne notes "undue censorship" as a key potential obstacle to an institutional model. This undue censorship could be caused by either a misconceptualised electoral institution or through further extension of the constraints of institutionally bound expression into other areas of society. Ultimately however, Neuborne is comfortable that the significant difference between the special nature of elections and the rest of society generally means the risk on undue restriction is limited.

48 Geddis, above $\mathrm{n} 5$ at 54.

49 Baker, above n 35, at 34.

50 Geddis, above $\mathrm{n} 5$, at 60 .

51 Baker, above n 35, at 24 and 25. 
"institution" of elections to ensure its optimal operation. ${ }^{52}$ Electoral expression can then be seen as a narrower subcategory of political expression, serving a particular limited purpose within the functioning of a democratic state - specifically, within the electoral institution. ${ }^{53}$

That expression can have institutional bounds is not, of itself, exceptional. There are many instances where expression is categorised and institutionally bounded because of its content or the time, place or nature of the expression. ${ }^{54}$ Indeed, even political expression is frequently allowed to be bounded within the context of particular institutions. ${ }^{55}$ By enabling the identification of a distinct category of "electoral expression", an institutional view of elections inevitably allows for the possibility of state or judicial intervention or regulation in the way expression occurs within the institution and the rules and norms that comprise it. Indeed, electoral campaigns are already subject to many regulations not found in other spheres. ${ }^{56}$

Baker takes a process-orientated view of the electoral system, arguing that it can be regulated to enhance the "democratic nature of the process". ${ }^{57}$ Elections serve as the mechanism by which political opinion, created mostly by general political expression, is transformed into political power. ${ }^{58}$ This is important. Where there is the possibility for state intervention in the institution, it should be limited to enhancing the democratic nature of the electoral institution. ${ }^{59}$

52 Neuborne, above n 35 , at 801 .

53 Baker, above n 35, at 26.

54 Thomas Scanlon "A Theory of Freedom of Expression" (1972) 1 Philosophy and Public Affairs 204 at 209; H J McCloskey "Limits to Freedom of Expression" (1982) 16 Journal of Value Inquiry 47; C Edwin Baker "Unreasoned Reasonableness: Mandatory Parade Permits and Time, Place and Manner Regulations" (19831984) 78 Nw U L Rev 937; William J Brennan "The Supreme Court and the Meiklejohn Interpretation of the First Amendment" (1965) 79 Harv L Rev 1 at 13; W Sadurski Freedom of Speech and Its Limits (Kluwer Academic Publishers, Netherlands, 2001).

55 Some examples of institutionally bounded regulation of political expression are given by Baker, above n 35, at 21. These include the regulation of speeches or debates in Congress or Parliament (such as the length of a speech); regulation of the questions that can be asked, and the nature of the answers that may be given in court and limits on what government officials can say about government policy. Other examples may include non-legal institutional rules like the principle of unanimity found within the convention of Cabinet collective responsibility. Neuborne, above n 35 , also gives union elections and commercial capital markets as yet more examples of bounded institutions.

56 Jacob Rowbottom "The Case against Political Advertising on the Broadcast Media" in KD Ewing and S Issacharoff (eds) Party Funding and Campaign Financing in International Perspective (Hart Publishing, Oxford, 2006) 77 at 82.

57 Baker, above n 35, at 26.

58 Ibid, at 28.

59 Courts in the United States have been willing to allow regulations that enhance communications so long as they remain within the boundaries of that form of discourse. Where a regulation infringes on an established form of discourse courts have been far more likely to deem the regulation unconstitutional. See Daniel 
To illustrate that elections can and are seen as an institution, Baker engages in an examination of American case law. The United States Supreme Court has found that exclusion of a racial group from an election, even during the height of segregation, is unconstitutional discrimination. ${ }^{60}$ The Court has held that parties themselves may be regulated regarding their access to the ballot, ${ }^{61}$ and that a ban on campaigning within 100 feet of a polling station on election day was not unconstitutional despite limiting core political expression. ${ }^{62}$ Further, in two separate decisions the courts have upheld a candidate's right to access broadcasting resources in the campaign period. ${ }^{63}$ Finally, the Court has also upheld restrictions on corporate electoral expression, although this has since been overruled. ${ }^{64}$ These conclusions are consistent with these issues being seen as part of an institutionally bounded electoral process. ${ }^{65}$ The dictum in the aforementioned authorities leads Baker to conclude that: ${ }^{66}$

[t]he Court can hardly stop short of the conclusion that the electoral context permits speech limitations that would not be permissible elsewhere ... [the cases mentioned] implicitly accept the view that campaign speech is part of a legally structured, institutional realm in which speech can be regulated.

A competing argument is that election campaigns heighten the importance of debate and opinion formation and thus should be free from regulation, to enable opportunities for discussion to come about "from the play of market forces" ${ }^{67}$ However, Baker argues that voters' opinions are formed in the wider political sphere (within which political expression is free) and that the focus of campaigns

Halberstam "Commercial Speech, Professional Speech, and the Constitutional Status of Social Institutions" (1999) 147 U Penn L Rev 771 at 828.

60 Terry $v$ Adams 345 US 461(1953).

61 Jenness $v$ Fortson 403 US 431(1971).

62 Burson v Freeman 504 US 191(1992).

63 CBS v FCC 453 US 367 (1981); Syracuse Peace Council v FCC 867 F 2d 654 (DC Cir 1989).

64 Austin v Michigan State Chamber of Commerce 494 US 652 (1990). However, a recent decision of the Supreme Court has overruled Austin, allowing political spending by corporations. See Citizens United v Federal Electoral Commission 558 US 50 (2010).

65 It is not just United States authorities that evidence this point. The House of Lords in $R v$ BBC ex parte ProLife Alliance [2003] UKHL 23, [2004] 1 AC 185 upheld the BBC's decision to refuse to publish an electoral advertisement by an anti-abortion political party showing images of aborted foetuses on the grounds that it was offensive. This shows again that certain bounds may exist within the electoral institution.

66 Baker, above n 35, at 33 .

67 Lillian BeVier "Campaign Finance Reform: Specious Arguments, Intractable Dilemma" [1994] 94(4) Colum L Rev 1259 at 1260. 
is essentially an "employment" decision, requiring voters to use the opinions they have developed to select their preferred candidates. ${ }^{68}$

Briffault acknowledges the procedural aspects of the electoral institution in transforming voice into governance, but he rejects Baker's claim that political opinions are predominantly formed before the electoral period. Rather, voters need to be able to put forward and consider alternative electoral choices. Briffault argues that communications can be considered to fall within the electoral institution if there is some possibility that it could affect the outcome of an election. ${ }^{69}$ Such communications can then be regulated, having regard to fundamental democratic values including "political equality, openness to participation, informed deliberation, and structured choice". ${ }^{70}$ However, Briffault does not expand on how likely, or how significant, such an influence must be. Neuborne suggests that electoral expression may be distinguishable through a temporal and descriptive definition, even if these are essentially arbitrary. ${ }^{71}$

The combined approach of Briffault and Neuborne provides a good characterisation of expression in the electoral institution. Briffault's criterion, while too wide to be useful without elaboration, provides a useful starting point for where, substantively, the boundaries of the institution are to be drawn. Complementing this, Neuborne provides guidance on how these boundaries are to operate in practice. Neuborne's illustration is a sound starting point: ${ }^{72}$

Speech by a candidate, or speech by others [descriptive] within 90 days of an election [temporal] that mentions a candidate in a manner clearly calculated to support or oppose her election [descriptive].

There must be some modifications to this definition. Expression "mentioning" a candidate is too narrow as this excludes obvious inferences and even opaque references that would have the same effect in substance. A broader definition may encompass references made in relation to a candidate, as understood by an ordinary citizen. Limiting the definition to a candidate is also too narrow, especially in countries where elections are primarily contested along party lines. The temporal element is necessarily arbitrary, but important, as this provides the most concrete outer limit of the expression occurring within the electoral institution. Setting this temporal limit at 90 days may encroach too much on healthy political expression; where this temporal limit is to be set is a

68 Baker, above n 35, at 34. If, as Baker acknowledges, political opinion is formed during wider political discourse, Neuborne's concern of "undue censorship" becomes of even more importance. The electoral institution must be well defined and as narrow as possible.

69 Briffault, above $\mathrm{n} 35$, at 1778

70 Ibid, at 1771 .

71 Neuborne, above n 35, at 809.

72 Ibid [text in square brackets added for clarification]. 
substantive judgment to be made by a particular society. Given these modifications, a refined definition of electoral expression could provide:

Expression by a candidate or expression by others within [x] days of an election that makes reference to

a party or candidate, as understood by an ordinary citizen, in a manner clearly calculated to support or oppose the election of that party or candidate.

Having described a broad model of institutionally bounded elections, the question remains, is a similar conception of an electoral institution recognised in New Zealand? I next examine a series of New Zealand decisions that support the idea that electoral expression and behaviour, as scrutinised by the judiciary, can be viewed as part of a distinct institution.

\section{B Is Electoral Broadcasting in New Zealand Institutionally Bounded?}

An analysis of New Zealand's electoral broadcasting legislation and case law shows that the treatment of expression, at least expression through the medium of broadcast advertising, during election periods is broadly consistent with the aforementioned institutionally bounded conception of electoral expression. A recent line of cases dealing primarily with broadcasters' actions during elections supports the proposition that the New Zealand judiciary conceives of elections, and the expression that occurs within them, as something special and distinct from the general political environment. In particular, the judiciary has found a greater willingness to scrutinise expression occurring within an electoral context where judicial restraint would otherwise be expected. The judiciary has consciously held those participating within the electoral broadcasting arena to a higher standard than if they were engaging in other political activities, requiring such actors to uphold democratic responsibilities, even if they are operating as a private enterprise.

Elections in New Zealand take the form of a special institution with election campaigns forming "a central part of the process of structured choice and democratic deliberation that constitutes an election". ${ }^{73}$ The recognition in New Zealand's judicial decisions of an institutional conception of elections leads to the identification of an institutionally bounded realm of election expression, separate from other political expression. In contrast to Baker's model, it does not seem that the New Zealand electoral institution, at least since the advent of proportional representation, is limited to mere process or selection of candidates. Indeed, what is said during this pre-election period appears to be important to voters' opinion formation. ${ }^{74}$ This adds even more weight to the argument that an

73 Briffault, above $\mathrm{n} 35$, at 1769.

74 Dunne v CanWest TVWorks Ltd [2005] NZAR 577 (HC) at [10] and [13] [Dunne]. Consider the evidence of Professor Levine and United Future leader Peter Dunne. In 2002, United Future's polling went from 0.4 per cent before the televised leaders' debate to shortly after receiving 6.9 per cent of the vote on election night. 
election ought to be conceptualised as a special institution entailing its own rules, responsibilities and a heightened level of judicial scrutiny. ${ }^{75}$

\section{The Legislative Framework of Elections and Electoral Bodies}

The first indications of the special rules comprising New Zealand's electoral institution are found in statute. The Broadcasting Act 1989 defines a class of "election programmes",76 and regulates who may create, purchase and broadcast such programmes. ${ }^{77}$ The High Court has noted that during an election "the Broadcasting Act makes it clear that broadcasters are not free to do as they choose", noting the tight legislative institutional framework governing how expression occurs through the broadcast media during an election. ${ }^{78}$

These strong institutional bounds give the State alone power to apportion direct broadcast access for political parties. ${ }^{79}$ The body through which the State manages elections and allocates broadcast access is the Electoral Commission. The Commission is an independent Crown entity and this independence is fundamental to the electoral institution. ${ }^{80}$ The Court of Appeal has recognised that the Electoral Act 1993 gives the Commission a "significant" and "special" status. ${ }^{81}$ This status derives from it holding "a key position and serves a number of vital functions in the operation of the nation's electoral system". ${ }^{82}$ Members of the Commission, like the judiciary, are protected from removal. ${ }^{83}$ Private industry boards, like the Advertising Standards Complaints Board, are subsidiary to the Commission on matters relating to an election. ${ }^{84}$ The statutory provisions defining the nature, membership and powers of the Electoral Commission highlight the weight given to the electoral institution and its key organs in New Zealand.

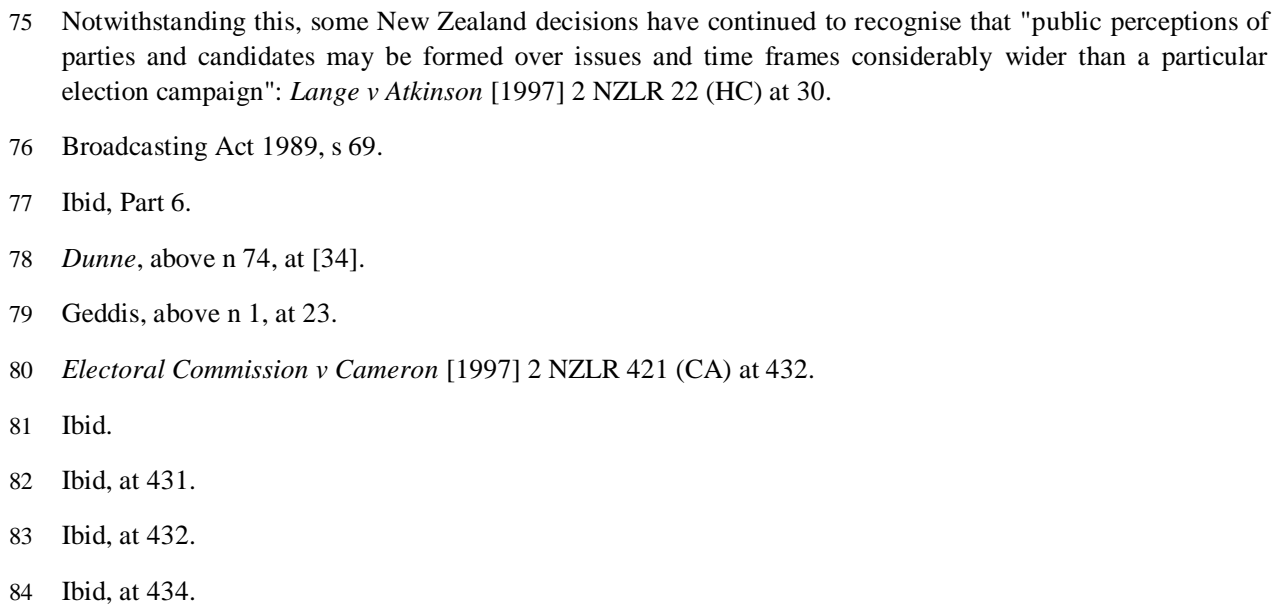


The Broadcasting Act contains a legislative definition of "election period". 85 General elections in New Zealand are founded on a legislative framework. ${ }^{86}$ Elections must be held within no more than three years. ${ }^{87}$ As Issacharoff notes, parliamentary democracies have a natural election period, "beginning with the calling of elections and ending with the elections themselves", creating a readymade institutional boundary. ${ }^{88}$ Indeed, so important is the electoral institution that a number of provisions are "entrenched". ${ }^{89}$ Such a reconstitution of Parliament's powers highlights the treatment of elections as special institutions, related yet separate from the ordinary realm of political activity.

\section{Judicial Perceptions of the Electoral Institution}

The judiciary's treatment of electoral broadcasting also evidences the recognition of an institutionally bounded conception of electoral expression. There are two key themes present in these decisions. First, actors within the electoral institution are more open to judicial scrutiny. Indeed, it would appear from some authorities that almost any actor participating in the electoral arena, at least within a public forum, may fall subject to enhanced scrutiny. On the other hand, a number of decisions in this area have been cautious and have seen courts unwilling to overstep their conventional role in the democratic process. Secondly, the courts have actively required higher standards of conduct from those participating in the electoral institution, relative to other political activity. These two themes represent judicially imposed constraints and responsibilities on those wishing to exercise expression in the electoral arena. As noted above, the focus of these case studies will be on electoral broadcasting. However, the themes discussed are also applicable to general electoral advertising.

\section{Greater exposure to review}

The comparative willingness of the judiciary to scrutinise particular activities can indicate both whether the courts consider elections to form a special institution (compared to other, more general, political activities) and, if such an institution does exist, what its extent is. The courts have typically shied away from intruding into political expression and have recognised that editorial decisions of the media generally ought to receive sufficient freedom. ${ }^{90}$ This is particularly so in political matters

85 Broadcasting Act 1989, s 69. That Act states that an "election period" begins with writ day and ends with the close of the day preceding polling day.

86

Electoral Act 1993; Constitution Act 1986.

87 Constitution Act 1986, s 17.

88 Samuel Issacharoff "The Constitutional Logic of Campaign Finance Regulation" (2008) Pepp L Rev 373 at 378.

89 Electoral Act 1993, s 268.

90 Mangu v Television New Zealand Ltd [2006] NZAR 299 (HC) at [22] [Mangu]. The Court cited a number of authorities to support the importance of the media's right to expression and editorial independence: Lange $v$ 
where the media forms part of a public accountability mechanism for elected officials. However, a number of decisions illustrate that the courts treat their scrutinising role in elections as different than during ordinary political discourse. The context of an election may be an "exceptional and compelling" one, ${ }^{91}$ where judicial intervention is necessary.

This scrutiny has transcended the "public/private divide" and has seen the courts entering controversial new territory. In Dunne v CanWest TVWorks Ltd (Dunne), Ronald Young J in the High Court held that TV3, a private television company, by virtue of its decision to host a preelection leaders' debate, was both amenable to judicial review and consequently subject to general public law obligations and responsibilities. ${ }^{92}$ TV3 had initially selected only the six most popular party leaders based on a recent poll. The plaintiffs were leaders of the two parliamentary parties that had been omitted from the debate and argued that TV3's selection criteria was flawed as the polling difference between a number of parties was within the poll's margin of error. By choosing to hold the pre-election leaders debate TV3 had put itself "into the public arena", creating a significant possibility of influencing the outcome of the election. ${ }^{93}$ In an earlier decision, TV3 Network Services $v$ The Prime Minister (Rt Hon Helen Clark), Ronald Young J had held that a pre-election interview of the Prime Minister, again conducted by TV3, should be judicially scrutinised as it occurred at "the most sensitive time possible, during an election campaign". ${ }^{94}$ Again, the justification centred on the potential effect of the interview on both the outcome of the election and possible government formation. ${ }^{95}$ These statements bear a striking similarity to Briffault's conception of electoral expression as that which may affect the outcome on an election and suggest the recognition, and also share similarities with the definition of electoral expression suggested above.

Elections operate in a "critical context"96 and this context alone can be used to determine the nature and extent of the electoral institution. Dunne highlights the importance of broadcasting during election periods, particularly in the manner in which the Court effectively distinguished electoral activity from other political discourse. What would undoubtedly have been an uncomfortable intrusion by the Court at any other time became the subject of judicial review within

Atkinson [1998] 3 NZLR 424 (CA) at 465-467; Auckland Area Health Board v Television New Zealand Limited [1992] 3 NZLR 406 (CA) and TV 3 Network Services Limited v Fahey [1999] 2 NZLR 129 (CA).

91 Mangu, ibid, at [22].

92 Dunne, above n 74, at [37]-[47].

93 Ibid at [34].

94 TV3 Network Services v The Prime Minister (Rt Hon Helen Clark) HC Wellington CIV-2003-485-1655, 10 February 2004 at [48].

95 Ibid, at [48].

96 Alliance Party (CA), above n 3, at [35]. 
the institutional context of an election. ${ }^{97}$ Had the facts of Dunne occurred in the days after an election it seems unlikely that the Court would have found the same comfort, or need, in scrutinising a private broadcaster in this regard, especially its production decisions.

The distinction seen in Dunne between expression occurring within the electoral institution and general political discourse is highlighted by comparison to the decision of the High Court in Ransfield v Radio Network Ltd (Ransfield) ${ }^{98}$ In Ransfield, the plaintiffs were actively involved in debate on tenancy and Māori issues. ${ }^{99}$ The plaintiffs had been banned by the Radio Network from participating in a talkback radio programme and sought relief under both the Broadcasting Act and the Bill of Rights Act. ${ }^{100}$ After finding that no cause of action lay under the Broadcasting Act, Randerson $\mathbf{J}$ identified the importance of free political expression and implicitly accepted, at least for the purposes of the interlocutory proceeding, that the plaintiffs were exercising political expression. ${ }^{101}$ However, Randerson $\mathbf{J}$ found that the Radio Network's provision of talkback radio, while performing an important public role in enabling the exercising of expression, ${ }^{102}$ was not sufficient to displace the reality that the Radio Network was performing a private commercial operation for the profit of its shareholders. Thus they were not bound by the Bill of Rights Act and the Court would not intervene. ${ }^{103}$ Ransfield and Dunne sit uncomfortably unless viewed in the context of the electoral institution. While both the Radio Network and TV3 were private broadcasters making decisions to best enhance their profitability, TV3 had chosen to directly participate in the electoral institution. Viewed in this way, the cases again suggest that there is something special about the judiciary's perception of expression within the electoral institution that makes state intervention more appropriate than during ordinary political discourse.

The heightened willingness of the courts to review expression and activity falling within the electoral institution, as in Dunne, has not been universally supported. In Alliance, the Court of Appeal went so far as to say that "[i]n matters relating to the election of Members of Parliament, this Court should not intrude any further than is absolutely necessary to determine lawfulness." 104 This comment came in the context of the Court's decision to reject an application to inquire into an

97 Some scholars still consider the Court's intrusion in Dunne to be too far. For a critical analysis of whether TV3 ought to have been amenable to review, see Dean R Knight "Dunne $v$ Canwest TVWorks Ltd: Enhancing or Undermining the Democratic and Constitutional Balance?" (2005) 21 NZULR 711.

98 Ransfield v Radio Network Ltd [2005] 1 NZLR 233 (HC) [Ransfield].

99 Ibid, at [7].

100 Ibid, at [1] and [3].

101 Ibid, at [38]-[43].

102 Ibid, at [72].

103 Ibid, at [73].

104 Alliance Party (CA), above n 3, at [43]. 
allegation that the Electoral Commission had factored irrelevant considerations into its allocation of electoral advertising funds, a matter the Court considered moot. Given this, the wider applicability of the Court's statement is not clear. The statement may either be seen as a call for greater judicial restraint, contrary to Dunne, or instead a mere recognition of the need for judicial pragmatism. It is also unclear that the qualifier absolutely adds to the statement; either it is necessary for the court to determine lawfulness or it is not. In the context of the decision, the statement is most likely a call for pragmatism - the courts should not intervene simply for the sake of intervention if it is unlikely to have any meaningful effect.

Another case posing difficulties for the decision in Dunne is Mangu v Television New Zealand Ltd (Mangu). ${ }^{105}$ The plaintiff, a candidate in an electorate, sought to challenge the broadcasting of a television news item on the contest for the electorate seat she was standing in on the basis that it had failed to mention her campaign. The news item instead focused on the two best performing candidates according to a recent poll. Lang $\mathrm{J}$ held that, in this case, TVNZ was not amenable to judicial review, nor was it performing a public function suitable to engage the Bill of Rights Act. ${ }^{106}$ Lang $\mathbf{J}$ emphasised the freedom of editorial expression, whereas Ronald Young $\mathbf{J}$ strongly sought to uphold the right of voters to be informed. ${ }^{107}$

Interestingly, Mangu was heard very shortly after the decision in Dunne was released, but despite the facts appearing to share many similarities, Lang J distinguished Dunne. His Honour accepted that both counsel had submitted that the facts of Mangu were "quite different" to those in Dunne and that the principles set out by Ronald Young $\mathrm{J}$ were not of assistance, but no detailed reasoning for this decision was given. ${ }^{108}$ It is far from obvious how the two cases are so sufficiently different that Dunne could be distinguished without further reason. Arguably, Mangu's claim was at least as strong as that of the plaintiffs in Dunne. ${ }^{109}$

Mangu could be seen as representing the outer limits of the electoral institution in New Zealand. While the courts may be willing to intervene in programmes specifically designed for the airing of political views by candidates, they may allow greater deference to editorial discretion of the media in non-partisan news items of a merely informative nature. Indeed, it would arguably be hard to conceptualise the information generated by such a news item as an "electoral message", especially

105 Mangu, above n 90

106 Ibid, at [19].

107 Michael Taggart "Proportionality, Deference, Wednesbury" [2008] NZ Law Review 423 at 467.

108 Mangu, above n 90, at [54].

109 Saul Holt "Television Coverage of Election Campaigns: Do Broadcasters have Public Law Obligations?" (2005) 4 NZPGLeJ 1 at 8 
when compared to a party leaders' debate as in Dunne. ${ }^{110}$ However, the Court in Mangu appears to have overlooked the key question - did the news item fall within the electoral institution? One of Mangu's key concerns was that the failure to include comment on her candidacy in the report diminished both her visibility and prejudiced her campaign by making it appear that she lacked "tangible support". ${ }^{11}$ Applying Briffault's criterion of whether the expression may affect the outcome of an election, a proposition similar to those posed in Dunne and TV3 Network Services $v$ Prime Minister (Rt Hon Helen Clark), Mangu's case would seem to be one warranting similar judicial scrutiny. Indeed, Ronald Young J noted in Dunne that one of the key features of TV3's leaders debate which made it open to judicial scrutiny and created its public law obligations was that the programme, at least in part, assisted "all voters to inform themselves of the leaders and the policies of the political parties contesting the election". ${ }^{112}$ It could surely also be said that at least part of the purpose of a television news item covering the contest for a particular electorate is to inform voters of which candidates are standing.

In any case, the haste of the interlocutory proceedings combined with the concession of Mangu's counsel that TVNZ had the right to place the emphasis in the programme on the two best polling candidates meant that the opportunity of the court to address the nature of electoral expression was insubstantial. ${ }^{113}$ Another argument may be that Mangu is a case where counsel and judge alike failed to appropriately frame the expression in question. Lang J noted that: ${ }^{114}$

Mr Illingworth [counsel for Mangu] frankly conceded that, if his argument was correct, every decision made by TVNZ in relation to the content and presentation of its news programmes, and One News in particular, would potentially be subject to judicial review.

In my view, this issue could have been overcome by framing the news item as part of the electoral institution. Rather than conceding that all of TVNZ's editorial decisions were potentially subject to review, counsel for Mangu could have argued that judicial scrutiny attaches to the fact

110 See also Lange v Atkinson [2000] 3 NZLR 385 (CA). In the context of qualified privilege the Court of Appeal noted the importance of the nature and purpose of the publication in question within the electoral context; this may determine the seriousness of the Court's scrutiny. The Court stated, at [13]:

[A]s an example of circumstances where the subject-matter may not be determinative, it is questionable whether a one-line reference to alleged misconduct of a grave nature on the part of a parliamentary candidate reflecting on his or her suitability, appearing in an article in a motoring magazine about that person's activities in motor sport, should receive protection. By contrast, the inclusion of such material in the course of a lengthy serious article on a coming election may justifiably attract the protection.

111 Mangu, above n 90, at [56], [57] and [62].

112 Dunne, above n 74, at [34]

113 Mangu, above n 90, at [28].

114 Ibid, at [26]. 
that the programme occurred within the electoral institution. ${ }^{115}$ This would have greatly limited the number and type of news programmes that could have been subject to judicial scrutiny, in the same way as it was not suggested in Dunne that every debate or programme TV3 screened would be potentially subject to judicial review. An argument for a narrower threshold of judicial scrutiny in this instance may well have proven more palatable to the Court.

Goulden v Wellington City Council may be seen as a failure of the Court to appropriately consider the electoral institution. The plaintiff, a sitting councillor and a mayoral candidate, reviewed his censure by the Council after it found he had breached the Council's Code of Conduct. ${ }^{116}$ The Code of Conduct required councillors to avoid criticising any employee of the Council (including the Chief Financial Officer). ${ }^{117}$ In the course of his campaign, Goulden placed an advertisement in a local newspaper criticising the spending activities of the Mayor and the Council's Chief Financial Officer. ${ }^{118}$ While the case turned on the procedures followed by the Council in reprimanding Goulden, little was made of the context of the advertisement itself, namely that it was published as part of Goulden's electoral campaign. The concept of an electoral institution and electoral expression is not just an expression restricting concept; it can be used to justify judicial recognition of freedom of expression where it would otherwise be restricted. Given that the Code of Conduct did not create an absolute prohibition against councillors criticising employees, this was a case where it may have been appropriate for the Court to have found that within the electoral institution more leeway ought to be given to candidates in the course of their campaigns.

An interesting application of the public/private divide during elections, albeit outside the context of broadcasting, has come in a number of decisions on internal candidate selection in political parties. In Peters $v$ Collinge the Court held that political parties were legally "private bodies" subject to private law and their own internal rules. ${ }^{119}$ Consequentially, parties were free to select candidates as they wished. However, this position softened in the later decision of the High Court in Payne $v$ New Zealand National Party. ${ }^{120}$ Given the fundamental importance of political parties to the electoral institution, the focus on parties as private entities may appear contrary to the recognition of such an institution. However, it may instead be seen to aid the drawing of boundaries - when parties

115 Dunne, above n 74, at [34]. The key being in Dunne that "TV3 has decided it will undertake, immediately before New Zealand's general election, a leaders' debate."

116 Goulden v Wellington City Council HC Wellington CIV-2004-485-1, 21 April 2006.

117 Ibid, at [2].

118 Ibid, at [4].

119 Peters $v$ Collinge [1993] 2 NZLR 554 (HC) at 575.

120 Payne v New Zealand National Party [2008] 3 NZLR 233 (CA). For further commentary on this litigation, see Andrew Geddis "Fighting the 2008 election in the courts" [2008] NZLJ 279 at 280; Andrew Geddis "Mr Payne doesn't go to Wellington" [2009] NZLJ 289. 
act in public, such as leaders debates and advertising, they are undoubtedly acting within the electoral institution - but when they act internally, even when selecting a candidate for an election, they are making a decision in a purely political sphere, separate from the electoral institution.

\title{
2 Higher standards of conduct required curing an election campaign
}

In concert with increased exposure to judicial scrutiny within the electoral institution, the courts have also recognised that actors in this context will be subject to higher standards of conduct. This again highlights a delineation of an institutionalised model of elections and electoral expression. Conduct that may be acceptable in the context of ordinary political discourse may fail to reach the heightened standards created by principles of fairness and democracy during an election campaign.

The "sensitive time" that exists during an election has been found to create public responsibilities of fairness and balance upon broadcasters, even private broadcasters. ${ }^{121}$ These responsibilities sit in addition to the broadcasting standards and Broadcasting Act requirements otherwise present. The nature of these additional standards of fairness and balance are particular to the electoral context. Again, this serves to suggest the existence of a special "electoral institution".

Broadcasters participating in an electoral context are required to act with "scrupulous impartiality". ${ }^{122}$ A forceful interview conducted with the Prime Minister during an election campaign relating to allegations of a cover-up made over a release of genetically modified corn did not, of itself, necessarily breach any broadcasting standards. ${ }^{123}$ However, the fact that the interview occurred during an election campaign - "the most sensitive time possible" - required a similarly forceful challenge to the accuser to maintain impartiality. ${ }^{124}$ Whether a standard was breached by the interview treating the accuser less forcefully would depend on context. Here, the context of an election campaign "clearly required forceful challenge of both accuser and accused". ${ }^{125}$ Further, it was noted by the Court that "a breach of the standards of balance, impartiality and fairness in a programme as significant as this (given it was broadcast during an election campaign) was a serious lapse by the broadcaster". ${ }^{126}$

Similar heightened standards have also been recognised by the courts in the interpretation of legislation. In Alliance, discussed above, the Court noted that the purpose of the tight regulation of

\author{
121 Dunne, above n 74, at [34]. \\ 122 TV3 Network Services v The Prime Minister (Rt Hon Helen Clark), above n 94, at [48]. \\ 123 Ibid. \\ 124 Ibid. \\ 125 Ibid. \\ 126 Ibid, at [62].
}


election broadcasting in New Zealand must be "the democratic principle of fairness of access". ${ }^{127}$ Despite finding that a misinterpretation had occurred on the ordinary words of the Act, without the need to resort to tools of statutory construction, the Court suggested in obiter that "statutory language should be read, if reasonably possible, in a way which facilitates the important democratic feature of dissemination of election messages". ${ }^{28}$ As noted earlier, this statement is phrased consistently with the so-called "principle of legality", that, in the words of Lord Hoffmann: ${ }^{129}$

In the absence of express language or necessary implication to the contrary, the courts therefore presume that even the most general words were intended to be subject to the basic rights of the individual.

The comments of the Court of Appeal recognise a distinct electoral institution in New Zealand encompassing, at the very least, its own institutional rights and principles regarding broadcasting access. It is not clear why the Court of Appeal chose the words "election messages" when it could have referred to "electoral programmes", as defined in the Broadcasting Act. This may indicate an attempt by the Court to allude to a wider principle, potentially one applicable to the wider electoral institution.

The comments of the Court of Appeal in Alliance are reminiscent of Ronald Young J's statements in Dunne. His Honour noted that a variable intensity of judicial review had been applied in New Zealand - where fundamental rights were in play, the standard of arbitrariness required "will not be high". ${ }^{130}$ Here, the Judge considered that citizens had a fundamental right "to be as well informed as possible before exercising their right to vote". ${ }^{131} \mathrm{TV} 3$ 's decision to include some parties within the poll's error rate but exclude others was sufficiently arbitrary in the context of an election to be deemed unreasonable by the Court. ${ }^{132}$ Again, the Court has recognised a higher standard of conduct exists within the electoral context.

Interestingly, a similar challenge to that in Dunne had previously arisen before the Broadcasting Standards Authority in 2002. ${ }^{133}$ There, the Authority had held that TVNZ's decision to exclude a

127 Alliance Party (CA), above n 3, at [11].

128 Ibid, at [35].

$129 R v$ Secretary of State for the Home Department ex parte Simms, above n 21, at 131.

130 Dunne, above n 74, at [43].

131 Ibid.

132 Ibid, at [45].

133 Christian Heritage Party v TVNZ BSA decision 2002-173. A further contrast to Dunne can be seen in a Scottish Court of Session decision in which the Scottish National Party sought to challenge the decision of the BBC to exclude its leader from a party leaders' debate preceding the 2010 United Kingdom's election. The Scottish National Party argued that this amounted to a failure by the BBC to adhere to the impartiality requirements in its Charter. Dismissing the petition, Lady Smith found the decision could not be said to be lacking in impartiality. However, this case was fundamentally different to Dunne as it involved a state 
non-parliamentary party from its "minor leaders debate", despite polling similarly to parliamentary parties that had been included, was within TVNZ's editorial discretion and had not breached standards. The Authority stated that to find a breach in this case would be contrary to the Bill of Rights Act. The Authority's decision has been criticised for undervaluing political expression and failing to recognise the "heightened importance of the balance standard in the circumstances" within the context of an election campaign. ${ }^{134}$

The preceding paragraphs identify an electoral institution in New Zealand. Where matters fall within the institution, the courts have shown a greater willingness to scrutinise activity and hold participants to a higher standard of conduct. These features represent the bounds of electoral expression and enable a distinct category to be identified. The recognition of a defined electoral institution can aid courts to decide whether the expression in question is electoral or whether it is general political express and enables a divergence of rules between these two spheres as appropriate.

\section{E Whose Institution is it?}

More must be said about just who "owns" the institution, that is, for whom does it exist to serve? Parties have a great interest in the dissemination of election messages, namely their freedom to impart such messages. Indeed, it is the rights of political parties and candidates that dominate jurisprudence on electoral expression. ${ }^{135}$ In my view, this is an unfortunately narrow consideration of the rights and interests involved in the dissemination of electoral messages. It risks marginalising the interests of key electoral stakeholders - voters.

Voters hold the key interest in the electoral institution. The dissemination of electoral messages is meaningless without the ability for voters to receive or seek it. The right of voters to receive information, especially at a low cost to them, is fundamental to ensuring effective participation. The right to vote is not complete if voters lack the ability to use their right without being as informed as possible (or at least as informed as they wish to be). ${ }^{136}$ An electoral choice is not a true choice if

broadcaster who was clearly amenable to review and there were no grounds on which to argue the BBC's decision was unreasonable. See Petition of Scottish National Party and Others for Judicial Review [2010] CSOH 56.

134 Claudia Geiringer and Steven Price "Moving from Self-justification to Demonstrable Justification - the Bill of Rights and the Broadcasting Standards Authority" in Jeremy Finn and Stephen Todd (eds) Law, Liberty, Legislation: Essays in Honour of John Burrows QC (LexisNexis NZ Ltd, Wellington, 2008) 295 at 329.

135 For a range of perspectives see generally Janet L Hiebert "Elections, Democracy and Free Speech: More at Stake than an Unfettered Right to Advertise" in K D Ewing and S Issacharoff (eds) Party Funding and Campaign Financing in International Perspective (Hart Publishing, Oxford, 2006) 269; Bradley A Smith "Faulty Assumptions and Undemocratic Consequences of Campaign Finance Reform" (1996) 105 Yale L J 1049; Samual Issacharoff and Pamela S Karlan "Hydraulics of Campaign Finance Reform" (1998-1999) 77 Tex L Rev 1705.

136 Roach v Electoral Commissioner [2007] HCA 43 at [85] per Gummow, Kirby and Crennan JJ. Further, in Dunne, above $\mathrm{n}$ 74, at [43], Ronald Young $\mathrm{J}$ argued that there is a "fundamental right of citizens in a 
voters lack an opportunity to become aware of alternatives. ${ }^{137}$ To this end, the electoral institution can be used to enhance the interests of voters by enabling them to be exposed to a breadth of electoral information and information. Indeed, this may go further to include facilitation of third party electoral discourse, but this issue is beyond the scope of this paper. ${ }^{138}$ The use of broadcast advertising is an important basis for discussing the interests of voters as this medium has the potential to provide electoral information to voters at a very low cost to them. ${ }^{139}$

This brief discussion of stakeholder interests in the electoral institution seeks to raise issues for further discussion, particularly how parties' rights to disseminate their electoral position impact upon voters' rights to receive a breadth of electoral messages and the role of institutional bounds on these interests. It is important for courts, public bodies and legislators to look beyond the political veil created by the party system to all stakeholders in the electoral institution. The implications and importance of the advertising using the medium of broadcasting to all participants in an election should be recognised. ${ }^{140}$ Voters are not only the primary stakeholder in the electoral institution but are also its beneficiaries. In this regard, emphasis on the rights of parties to speak is only as important as the ability of voters to listen.

\section{CONCLUSION}

The New Zealand judiciary continues to play a significant role in the development of electoral law, particularly that relating to broadcasting, with cases like Alliance having important implications for actors in the electoral broadcasting arena. An examination of New Zealand's electoral legislation and case law evidences the emerging conception of an electoral institution. The use and recognition of this model can help to define electoral expression as a distinct category of expression, separate

democracy to be as well informed as possible before exercising their right to vote". However, Taggart, above $\mathrm{n}$ 107, at 467 contended that such an absolute description of the prominence of a right was unhelpful in this case, preferring instead that the importance of rights were weighted on a case by case basis.

137 Australian Capital Television v Commonwealth [1992] HCA 45 at [24] per Deane and Toohey JJ.

138 This has been a particularly significant issue in a number of Canadian and English decisions. For commentary see generally Colin Feasby "Issue Advocacy and Third Parties in the United Kingdom and Canada" (2003) 48 McGill L J 11; Andrew Geddis "Liberté, Egalité, Argent: Third Party Election Spending and the Charter" (2004) 42 Alta L Rev 429; Andrew Geddis "'If Thy Right Eye Offend Thee, Pluck it Out': $R v$ BBC ex parte ProLife Alliance" (2003) 66 MLR 885.

139 Jacob Rowbottom "Media Freedom and Political Debate in the Digital Era" (2006) 69 MLR 489 at 512. Rowbottom notes that "even with the advent of so called 'new media', the dominant outlet for political news is still the broadcast media".

140 As Joan Baker notes, the broadcast resource "enables its owner to communicate ideas, attitudes and values to the people living in large geographic areas on a vast range of subjects at relatively low cost, is a powerful asset". Not only is it a powerful resource for those wishing to communicate information, but also for those people wishing to receive low cost information. Joan Baker "Free Speech and Federal Control: The US Approach to Broadcasting Regulation" (1976) 39 MLR 147 at 147. 
from political communication, comprised of specific rules, norms and principles. This yields a basic definition of electoral expression as expression relating to the election of a particular candidate or party which may influence the outcome of an election and falling within a particular temporal constraint.

Dunne and Ransfield are a striking contrast, giving an example of the weight courts may place on the nature of the electoral institution when they are scrutinising the treatment of expression. Those overtly acting in the broadcast of electoral expression should expect a higher judicial willingness to examine their behaviour. Further, those participating in this electoral sphere are also likely to be held to a higher stand of conduct, reflecting the importance of activity with direct influence on the democratic process. An institutionally bounded approach can have benefits for judges and counsel dealing with difficult matters involving a delicate balancing of rights where the recognition of a distinct category of electoral expression can aid argument. Mangu is a case in point. Had the Court considered the nature of its inquiry from the lens of an institutionally bounded conception of election expression it may have been possible, as it was in Dunne, to restrict amenability to review to the limited circumstance of an election. This would have avoided unnecessary fears of a "slippery-slope" of reviewability.

Courts, legislators and policy makers have an important role to play in defining and balancing the nature of interests between different stakeholders within the electoral institution. It is important that the question of who the electoral institution serves is not too narrowly defined. While the interests of parties are significant, this should not obscure the interests of the key electoral stakeholders - voters - for whom the electoral process ultimately exists to serve.

The concept of an electoral institution, and electoral expression defined with these bounds, is a useful concept that can assist courts and counsel when faced with the balancing of rights at election time. The approach of the courts has involved tacit recognition of this model, but a more express discussion of the special nature of elections and the balancing of rights therein would be valuable for actors in the electoral sphere. 